\title{
Chapter 13 \\ How Can We Identify Elite Schools (Where They Do Not Exist)? The Case of Ireland
}

\author{
Aline Courtois
}

\section{Introduction}

In the UK, there is hardly any debate on whether Eton and Harrow are elite schools or not. However, in countries where there is no visible, historically established elite, tied to equally visible historical institutions, there may not be such a clear consensus. For instance, what do elite schools look like in smaller or developing countries, in post-communist states, or post-colonial contexts? Do explicit or implicit criteria used elsewhere apply? Shifting the focus to a country like Ireland helps reconsider what we may otherwise take for granted when it comes to identifying elite schools.

Today there are 53 'fee-paying schools' in Ireland. ${ }^{1}$ They educate $6.7 \%$ of the school-going population. Their special status allows them to receive state funding (for teachers' salaries, building renovation and so forth), while charging uncapped student fees. They do not operate entrance examinations because academic selection is forbidden; but they can - and do - give priority to siblings and children of past pupils. A number of fee-paying schools charge fees unaffordable to most families. As a group, they largely outperform 'free' schools in the national league tables. Some occupy castles surrounded by vast expanses of parkland and sport fields; others are located in Georgian houses on prestigious streets; their past pupils' directories feature prestigious occupations across a broad range of spheres (judges, surgeons, CEOs, horse breeders, art gallerists, etc.). Despite all these indicators, surprisingly, Irish fee-paying schools are rarely conceptualised as elite schools. Arguably, the diversity within the fee-paying sector, the absence of explicit

\footnotetext{
${ }^{1}$ Thus called to differentiate them from other schools, which are in private ownership but fully subsidised by the state and therefore 'free'.
}

\author{
A. Courtois $(\bowtie)$ \\ Department of Education, University of Bath, Bath, UK \\ e-mail: a.d.m.courtois@bath.ac.uk
}


academic selection in these schools and their relative discretion (compared to the famous public schools of the neighbouring UK) make them less conspicuous than in other jurisdictions. In addition, the postcolonial context and the national narrative focused on 'meritocracy' and 'hard work' make discussions of class and inherited privilege difficult.

Cookson and Persell (1985) argued that in research on elite education, the relevant question is not 'if' elite schools play a role in the social reproduction of elites but 'how' they do it. Yet, such a situation, where schools are not designated or perceived as elite schools, poses a particular set of challenges to the researcher: How is the research object constructed? How is the field of research delineated and the appropriate research setting identified? Does it matter? When the 'if' is subject to debate, what is the setting where the 'how' should be investigated? This chapter examines these questions through a reflection on one aspect of my work on elite schooling in Ireland. The study employed a 'classic' qualitative methodology (interviews with staff and past pupils; observation and so forth), but in order to establish the legitimacy of my research object, I felt it was necessary to objectivise the category 'elite schools' in the Irish context. It is this particular aspect of my study and its relevance to my broader research aims, which I examine here.

\section{Identifying Elite Schools}

There has been a remarkable expansion of sociological studies of elite education in recent years. Some new contributions chart relatively unexplored territories in various regions of the world, while others examine contexts where elite schools are 'understated' (Forbes and Weiner 2008 on Scotland) or where the notion itself is 'a contradiction in terms' (Börjesson et al. 2015 on Sweden) or even 'taboo' (Deppe and Krüger 2015 on Germany). Drawing on Bourdieu's field analysis (1996), Börjesson et al. in this book convincingly establish which Swedish schools are elite schools. However, in countries where data on the social origins of students and/or reliable information on the educational backgrounds and trajectories of elites are not available, this approach is not possible.

The willingness to separate schools catering for elites from other (independent, Public, private) schools was central to earlier works. In the UK, Wakeford, (1969) selected 82 all-boys boarding schools; Weinberg (1967) selected 84; Walford (1986) reduced this number to 29. In the US, Cookson and Persell (1985) selected the 16 'most socially elite' schools by excluding girls' schools, day schools and other categories which, they argued, did not socialise students for power. As GaztambideFernandez (2009) suggests, their work partly relied on an 'apparent consensus' with earlier authors that these schools were indeed the most elite. Similarly, in the UK, the 37 schools identified in the 1869 Clarendon Report formed the core of the schools designated as elite in later research. 
Recent studies have unsettled this implicit consensus on historical prestige as an indicator of elite status for schools. With the rise of the private for-profit sector and the growing popularity of international schools, historically established schools may struggle to maintain their leading positions (McCarthy and Kenway 2014; Rivzi 2014). Further, analyses of the field of power or quantitative studies of elite pathways are no longer considered prerequisites in the construction of the research object. Researchers may simply select schools that they describe as leading', 'topranked' or 'privileged' - institutions that stand out in some way. However, where the notion of 'elite schools' is contested, it becomes necessary to objectivise this category.

\section{The Irish Case}

During preliminary fieldwork, a marked status hierarchy between the 53 schools became apparent. Fees varied widely, from $€ 3000$ to $€ 12,000$ for day students and from $€ 8000$ to over $€ 25,000$ for boarders. League tables made visible significant variations in academic performance from one school to another. Past pupils, well aware of the symbolic economy at play within the sector, would refer to one school as a 'knackers' school' and to another as a school for the 'super-elite', with supposedly 'more intelligent' pupils, such as 'sons of surgeons'. Some of these schools exerted such symbolic power that some interviewees grossly overestimated their fees, or believed that they still operated competitive entrance tests. One particular school was believed to be so 'elite' that its boarders were forced to swim in an outdoor pool every day of the year. Participants spontaneously sorted schools in various categories (old/new money; rugby/academic school) which complicated my own preliminary categories (Catholic/Protestant; boarding/day; single-sex/mixed; urban/rural). It seemed necessary to objectivise the identification of schools as elite by using criteria other than those of reputation, prestige or physical character.

\section{Connecting Elites to Elite Schools}

The analysis of social registers has led to fascinating studies of patterns of reproduction and social trajectories within the elites (e.g. Williams and Filippakou 2010; Ringer 1978; Reeves et al. 2017). Despite some limitations (editor bias, selfreporting - see Scott 1990, p. 163-172), social registers constitute useful resources to identify elites according to their own self-perception (Lewandowski 1974). In Ireland, the only recent register detailing individuals' educational history with reasonable consistency is The Irish Who's Who (Phelan 2006). The 1390 entries in this list of 'influential Irish' represent a wide array of individuals across various spheres of activity: aristocrats and celebrities feature alongside more discreet high civil 
Table 13.1 Number of entries by elite category and by type of school

\begin{tabular}{l|l|l|l|l|l}
\hline & Abroad & Ireland unknown & Irish non-fee-paying & Irish fee-paying & Total \\
\hline Business & 54 & 52 & 207 & 195 & 508 \\
\hline Arts & 51 & 41 & 87 & 50 & 229 \\
\hline Media & 19 & 12 & 88 & 25 & 144 \\
\hline Professions & 10 & 11 & 44 & 69 & 134 \\
\hline Politics & 19 & 8 & 83 & 21 & 131 \\
\hline Civil service & 7 & 12 & 46 & 8 & 73 \\
\hline Academics & 12 & 7 & 21 & 15 & 55 \\
\hline Clergy & 10 & 3 & 19 & 9 & 41 \\
\hline Sports & 2 & 7 & 21 & 4 & 34 \\
\hline Other & 7 & 6 & 26 & 2 & 41 \\
\hline Total & 191 & 159 & 642 & 398 & 1390 \\
\hline
\end{tabular}

servants and top surgeons - suggesting that a loose combination of reputational, positional and decisional criteria was used in the selection. In my analysis I sorted individuals in different categories based on their principal activity. Employees and owners of small businesses that serve the elites (hairdressers, fashion advisers, etc.) were transferred to the 'Other' category. While the high number of women may be attributed to the editor's desire to reflect a certain image of Irish society, the largest category of activity is business, which reflects (intentionally or not) the structure of power in Irish society. The results of my analysis of the 1390 entries are presented in Table 13.1.

In total 398 individuals attended a fee-paying school, representing $28.6 \%$ of the total or $38.3 \%$ of those educated at an identifiable Irish school. By contrast, at its peak in 2008-2009, the fee-paying sector educated a mere $8 \%$ of the population. $16 \%$ of all politicians (20\% of those who went to identifiable Irish schools) were past pupils of fee-paying schools but this proportion was 39\% (49\%) for business people and 52\% (61\%) for higher professionals (top architects and surgeons, accountants, judges, solicitors). This shows that fee-paying schools are not as central to the production of political elites (their educational and career backgrounds are relatively diverse) but that they play an important role for other segments (with various proportions and combinations in different schools). Especially in a country the size of Ireland (4.7 million inhabitants), it also raises questions about the social proximity between the business sector and the professions. In addition, a number of schools emerged with particularly high numbers of alumni. Blackrock College, in particular, had educated 3.3\% of those in the Irish Who's Who, which is comparable with the proportion of Eton alumni in the British Who's Who (Kirby 2016). Finally, among the 191 educated abroad, 166 were educated in the neighbouring UK (including 89 in Northern Ireland) and 35\% of these had been to Public Schools. A number were Irish-born but it was not possible to ascertain how many. As I focused on schools in Ireland, I did not investigate this segment further but the significance of international education certainly deserves further examination, especially in light of O'Neill's work on the transnational education of Irish elites historically (2014). 


\section{Mapping Fee-Paying Schools}

In order to identify elite schools as objectively as possible, Gatztambide-Fernández recommended the use of typological, scholastic, historical, geographical and demographic criteria (2009). But these, and others, do not necessarily apply to the Irish context. While typically, lists of schools historically identified as elite are used either as such or to define ideal-types that guide categorisations, the historical context in Ireland makes this difficult: Ireland used to be a British colony and as a result the oldest schools are Protestant, but the balance of power has long shifted. After the Irish Independence (1921), many Protestants left Ireland, leaving their schools gravely undersubscribed. Some repositioned themselves (as international and/or multidenominational for instance) and maintained their prestige, but others ended up merging, closing or slipping into the non-fee-paying sector (this distinction between fee-paying and non-fee-paying exists since 1967 when the Irish state started to directly subsidize secondary education). By contrast, schools established in the nineteenth century for the rising Catholic sub-elite gradually rose to prominence. In fact, the two oldest schools, both Protestant, recently defected to the nonfee-paying sector. ${ }^{2}$ Further, there is no specific accreditation or typology differentiating fee-paying schools from one another, and Gaztambide-Fernández's geographical criterion is not useful in a country the size of Ireland. Systematic records of pupils' socio-economic backgrounds are not accessible. Finally, while most researchers have more or less automatically excluded day schools, this is problematic in Ireland due to the overrepresentation of boarding schools in the Protestant sector, which owes mainly to the dispersed nature of this minority.

What may be the invariant properties of elite schools that could apply in Ireland? Given the wide variation in fees between these 53 schools, and the role fees play as economic barriers to entry, it seemed necessary to consider them as an indicator of social exclusivity. Rates of admission to high-point courses (rather than rates of progression to higher education) also seemed especially relevant given that these point to schools' ability to facilitate access to presumably 'elite-track' courses. ${ }^{3}$

Therefore, three groups were constituted: group (A) gathered the 15 schools with the highest number of alumni in the Who's Who; the 15 most expensive schools constituted group (B); and the 15 schools which were in the top 25 for admission to higher point courses, at least four times over the past 6 years, were selected to make up group (C). In giving these three criteria an equal weight, I assumed that they were of similar importance, reflecting at least what wealthy parents may look for in terms of prestige, social closure and promised futures. The number of schools selected in each group was also somehow arbitrary, guided by the assumption that

\footnotetext{
${ }^{2}$ Another two were also Protestant and the fifth was a Catholic boarding school at the centre of an abuse scandal after which enrolment figures plummeted.

${ }^{3}$ There are limitations with using league tables for this purpose: some students may apply to UK universities and/or take a 'gap year' after school; league tables are based on acceptance rates to Irish universities and therefore do not reflect these privileged strategies.
} 
Table 13.2 Intersection of groups A, B and $\mathrm{C}^{\mathrm{a}}$

\begin{tabular}{|c|c|}
\hline \multicolumn{2}{|l|}{ Group $1(\mathrm{~N}=5)$} \\
\hline Intersection of (A), (B) and (C) & 5 schools \\
\hline \multicolumn{2}{|l|}{ Group $2(\mathrm{~N}=5)$} \\
\hline $\begin{array}{l}\text { (A) and (B) } \\
\text { (B) and (C) } \\
\text { (A) and (C) }\end{array}$ & $\begin{array}{l}2 \text { schools } \\
\text { (none) } \\
3 \text { schools }\end{array}$ \\
\hline \multicolumn{2}{|l|}{ Group $3(\mathrm{~N}=20)$} \\
\hline $\begin{array}{l}\text { (A) only } \\
\text { (B) only } \\
\text { (C) only }\end{array}$ & $\begin{array}{l}5 \text { schools } \\
8 \text { schools } \\
7 \text { schools }\end{array}$ \\
\hline Group $4(\mathrm{~N}=23)$ & 23 other fee-paying schools \\
\hline
\end{tabular}

${ }^{a}$ Tables 13.2 and 13.3 reproduced from Courtois (2018)

the final number of schools would be considerably smaller than 53. Table 13.2 shows how these three groups intersect.

Groups 1 and 2 overlapped almost completely with my provisional list, with three of the five schools identified by insiders located in Group 1 and one in Group 2. A small, relatively new (1920s), boarding school tucked away in the countryside, came as a surprise - yet further research and fieldwork confirmed it was indeed one of the most exclusive schools in the country.

Except in Group 1, there is no overlap between schools scoring high on the 'economic' criterion and schools scoring high on the 'academic' criterion. The way groups A, B and C intersect echoes Bourdieu's chiastic structure (1996), in which the economic and intellectual poles are opposed but only faintly so, for most of these schools remain unaffordable to most families. With the exception perhaps of a few non-fee-paying all-Irish schools, there is no such thing in Ireland as a cheap top-performing school.

Beyond this, while the proportion of businesspeople is higher in some schools compared to others, numbers are too small - and spread over several generations to attempt to position these schools horizontally in relation to each other. However, examining their characteristics helps understand the general morphology and dynamics of the sector, as shown in Table 13.3.

Thus, with a more pronounced tendency to be boarding schools and to cater for boys, schools in Group 1 are closer to the traditional model of elite education as described by Wakeford (1969) or Cookson and Persell (1985). Schools in Groups 1 and 2 also operate more stringent criteria; are likely to recruit nationally rather than locally; and to operate scholarship schemes. Protestant schools, schools with an international orientation, and girls' schools are concentrated principally in Groups 3 and 4.

Arguably, all groups could be further sub-divided according to their religious ethos or their academic versus socially exclusive orientation. Even within Group 1, schools are highly differentiated (Courtois 2018). In addition, the hierarchy is fluid, for in Ireland, as elsewhere, the symbolic economy of elite schooling changes over time. Schools that were not overtly preoccupied with academic results may 
Table 13.3 Characteristics of schools in each group

\begin{tabular}{|c|c|c|c|c|c|c|c|c|}
\hline & $\mathrm{N}$ & $\begin{array}{l}\text { Share of } \\
\text { school-going } \\
\text { population }\end{array}$ & $\begin{array}{l}\text { Average } \\
\text { day fees }\end{array}$ & $\begin{array}{l}\text { Average } \\
\text { boarding } \\
\text { fees }\end{array}$ & $\begin{array}{l}\text { Average } \\
\text { number of } \\
\text { alumni in } \\
\text { the Who's } \\
\text { Who }\end{array}$ & $\begin{array}{l}\text { Share } \\
\text { of } \\
\text { boys }\end{array}$ & $\begin{array}{l}\text { Share of } \\
\text { schools } \\
\text { with } \\
\text { boarding }\end{array}$ & $\begin{array}{l}\text { Share of } \\
\text { Catholic } \\
\text { schools }\end{array}$ \\
\hline Group 1 & 5 & $0.7 \%$ & 6490 & 17,750 & 26 & $83 \%$ & $80 \%$ & $80 \%$ \\
\hline Group 2 & 5 & $0.8 \%$ & 6450 & 17,760 & 14 & $79 \%$ & $40 \%$ & $80 \%$ \\
\hline Group 3 & 20 & $3 \%$ & 5500 & 15,560 & 7 & $60 \%$ & $25 \%$ & $65 \%$ \\
\hline Group 4 & 23 & $2.2 \%$ & 4150 & 9050 & 2 & $39 \%$ & $39 \%$ & $56 \%$ \\
\hline
\end{tabular}

suddenly propel themselves to the top of the league tables; some may increase their fees substantially while others become free; a few have repositioned themselves as international schools (Courtois 2015b). This model, which stratifies schools only vertically, is helpful in identifying elite schools as a relatively objective category. It guided the selection of case studies for the qualitative aspect of my work.

Yet it is worth noting that schools in Groups 3 and 4 are not irrelevant. They may not be the elites' first choice; but in different ways, they make the culture of exclusion, privilege and high expectations, that characterises elite schooling, accessible to the upper-middle classes. In his study of corporate circles, Useem (1984) identified an 'inner circle' that organized class-wide solidarity. He argued that its morphology and culture prefigured the political direction of the broader sector. Thus, the 'inner circle' of elite education, represented by Group 1, is made up predominantly of expensive, all-boys, Catholic boarding schools, whose students are more likely than others to reach positions of power.

\section{What Does This Tell Us About the Field of Power and Elites in Ireland?}

Since Nader's statement on 'studying up' (1972), many works have highlighted the importance of researching elites, and their social and educational spaces, in order to better understand the character and training of those who drive inequality (e.g. Khan 2011, p. 7). But recently, researchers have voiced some reservations in relation to how much studies of elite schools can really tell us about elites and power. For instance, van Zanten (2016) argues that in most studies, the influence of schooling on the normative and functional integration of individuals in elite groups is assumed rather than demonstrated. While it is generally agreed, including by schools themselves, that elite schools shape their pupils in certain ways, not much is known about how (or if) they influence their students' future political orientations and decisions once in power.

As shown in Table 13.1, elite schools produce elites across a range of spheres. This only becomes significant in the light of qualitative findings. Interviews and observation reveal how social segregation and class privilege are normalised and 
legitimated in these settings (Courtois 2015a) and how schools cultivate class solidarity across the various elite segments they bring together (Courtois 2013, 2018). While arguably, other schools share such ideologies and practices to various degrees, this takes particular significance precisely because of the connection between elite schools and the spheres of economic and political power, which the mapping of the sector makes discernible. This connection does not in itself constitute evidence that elite schools play a part in producing an ideological consensus between economic elites and various arms of the state but, together with qualitative findings, it makes visible a number of parallels: the framing of meritocracy and the occurrences of 'class disgust' (Lawler 2005) that I detail in my work resonate with the neoliberal policing of the poor in Ireland; while schools' exclusive and exclusionary social and cultural practices mirror those of the elites. Yet the overlap between the circle of elite school alumni on the one hand, and the elites ruling Ireland and/or benefitting from the way it is run on the other, is only partial. In addition, we only have an incomplete or tentative picture of both these circles. To the challenges identified by Howard and Kenway (2015) and van Zanten (2016) could be added that of elaborating conceptual and methodological tools to better understand political socialisation in and outside elite schools, and to trace the roots of social violence (and resistance) in these settings. This can hardly be dissociated from further research on the mechanisms of domination and their variations across societies, and should therefore account for the impact of globalization on the elites.

\section{Conclusion}

While global perspectives and methodologies in research on elite education are gaining in popularity, and are very productive, this chapter suggests that attention to local contexts remains relevant if we are to better 'map' elite education and understand its impact on societies. In relatively uncharted territories, it is necessary to fine-tune established and implicit criteria in order to take into account local specificities, spatial and historical dynamics and shifts of power. In the case of the present study, the research object thus delineated is not fixed or strictly bounded, nor can it 'tell' us everything we need to know about elite schooling in Ireland.

In the absence of accessible 'objective' data, different ways have to be found, which lead to a questioning of the invariant properties of elite schools across research contexts: are all elite schools 'historically elite'? Are they all well-known and widely recognised as such? Is their reputation always based on academic results? Is economic capital always something that needs to be hidden, or 'tamed'? Can national elite education landscapes change significantly under globalizing circumstances? 


\section{References}

Börjesson, M., Broady, D., Dalberg, T., \& Lidegran, I. (2015). Elite education in Sweden: A contradiction in terms? In C. Maxwell \& P. Aggleton (Eds.), Elite education: International perspectives (pp. 104-113). Abingdon/New York: Routledge.

Bourdieu, P. (1996). The state nobility: Elite schools in the field of power. Cambridge: Polity Press.

Cookson, P. W., \& Persell, C. H. (1985). Preparing for power: America's elite boarding schools. New York: Basic Books.

Courtois, A. (2013). Becoming elite: Exclusion, excellence and collective identity in Ireland's top fee-paying schools. In J. Abbink \& T. Salverda (Eds.), The anthropology of elites: Power, culture and the complexities of distinction. Basingstoke: Palgrave Macmillan.

Courtois, A. (2015a). 'Thousands living at our gates': Moral character, legitimacy and social justice in Irish elite schools. British Journal of Sociology of Education, 36(1), 53-70.

Courtois, A. (2015b). Internationalising practices and representations of the 'other' in second-level elite schools in Ireland. Globalisation, Societies and Education, 14(4), 560-576.

Courtois, A. (2018). Educating elites: Privilege and power in Ireland's top private schools. Basingstoke: Palgrave Macmillan.

Deppe, U., \& Krüger, H.-H. (2015). Elite education in Germany? Trends, developments and challenges. In C. Maxwell \& P. Aggleton (Eds.), Elite education: International perspectives (pp. 104-113). Abingdon/New York: Routledge.

Forbes, J., \& Weiner, G. (2008). Understated powerhouses: Scottish independent schools, their characteristics and their capitals. Discourse: Studies in the Cultural Politics of Education, 29(4), 509-525.

Gaztambide-Fernández, R. A. (2009). What is an elite boarding school? Review of Educational Research, 79(3), 1090-1128.

Howard, A., \& Kenway, J. (2015). Canvassing conversations: Obstinate issues in studies of elites and elite education. International Journal of Qualitative Studies in Education, 28(9), 1005-1032.

Khan, S. R. (2011). Privilege: The making of an adolescent elite at St. Paul's school. Princeton/ Oxford: Princeton University Press.

Kirby, P. (2016). Leading people 2016: The educational background of the UK professional elite. Sutton Trust Report.

Lawler, S. (2005). Disgusted subjects: The making of middle-class identities. The Sociological Review, 53(3), 429-446.

Lewandowski, O. (1974). Différenciation et mécanismes d'intégration de la classe dirigeante : L'image sociale de l'élite d'après le Who's Who en France. Revue Française de Sociologie, 15(1), 43-74.

McCarthy, C., \& Kenway, J. (2014). Introduction: Understanding the re-articulations of privilege over time and space. Globalisation, Education and Societies, 12(2), 165-176.

Nader, L. (1972). Up the anthropologist: Perspectives gained from studying up. In D. Hymes (Ed.), Reinventing anthropology (pp. 283-311). New York: Pantheon Books.

O’Neill, C. (2014). Catholics of consequence: Transnational education, social mobility, and the Irish Catholic elite 1850-1900. Oxford: Oxford University Press.

Phelan, B. (2006). Who's Who in Ireland. The Influential Irish. Dublin: Madison.

Reeves, A., Friedman, S., Rahal, C., \& Flemmen, M. (2017). The decline and persistence of the old boy: Private schools and elite recruitment 1897 to 2016. American Sociological Review, 82(6), 1139-1166.

Ringer, F. K. (1978). The education of elites in modern Europe. History of Education Quarterly, $18(2), 159-172$.

Rizvi, F. (2014). Old elite schools, history and the construction of a new imaginary. Globalisation, Societies and Education, 12(2), 290-308.

Scott, J. (1990). A matter of record. Cambridge: Polity Press. 
Useem, M. (1984). The inner circle: Large corporations and the rise of business political activity in the US and UK. Oxford: Oxford University Press.

Van Zanten, A. (2016). Introduction. La formation des élites : pour une approche généraliste, compréhensive et comparative. L'Année sociologique, 66(1), 73-80.

Wakeford, J. (1969). The cloistered elite: A sociological analysis of the English public boarding school. London: Macmillan.

Walford, G. (1986). Life in public schools. London: Methuen.

Weinberg, I. (1967). The English public schools. London: Atherton.

Williams, G., \& Filippakou, O. (2010). Higher education and UK elite formation in the twentieth century. Higher Education, 59, 1-20.

Open Access This chapter is licensed under the terms of the Creative Commons Attribution 4.0 International License (http://creativecommons.org/licenses/by/4.0/), which permits use, sharing, adaptation, distribution and reproduction in any medium or format, as long as you give appropriate credit to the original author(s) and the source, provide a link to the Creative Commons license and indicate if changes were made.

The images or other third party material in this chapter are included in the chapter's Creative Commons license, unless indicated otherwise in a credit line to the material. If material is not included in the chapter's Creative Commons license and your intended use is not permitted by statutory regulation or exceeds the permitted use, you will need to obtain permission directly from the copyright holder.

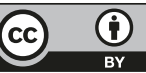

